\title{
USAHA PEMBIBITAN TERNAK BABI MAULAFA
}

Tri Anggarini Y. Foenay, Theresia Nur Indah Koni

Jurusan Peternakan - Politani Negeri Kupang

Email: anggarini.foenay@gmail.com

\begin{abstract}
ABSTRAK
Tujuan dari kegiatan IbM adalah meningkatkan pendapatan kelompok melalui usaha pembibitan ternak babi. Metode yang digunakan dalam kegiatan ini adalah penyuluhan, pelatihan, demplot,monitorinh dan evaluasi. Dalam IbM ini dilakukan beberapa kegiatan seperti perbaikan kandang, pengadaan bibit ternak, penyuluhan, pembuatan pakan,perkawinan ternak, penanganan kelahiran ternak, penjualan anak babi. Kegiatan ini telah berhasil, hal ini dilihat dari keikutsertaan, keaktifan serta berpengaruh pada peningkatan pendapatan kelompok binaan, karena kelompok dilatih untuk membuat pakan ternak babi sendiri maka terjadi penghematan biaya pakan sebesar Rp. 256,500 pada mitra, bila dibandingkan dengan menggunakan pakan babi komersial
\end{abstract}

Kata kunci : pembibitan ternak babi, kelompok peternak ukitauk

\section{PENDAHULUAN}

Ternak babi merupakan salah satu ternak yang digunakan oleh masyarakat Nusa Tenggara Timur (NTT) dalam acara-acara adat, selain itu ternak ini merupakan salah satu sumber protein hewani. Masyarakat NTT umumnya selalu memelihara ternak ini dengan jumlah pemeliharaan 2-10 ekor per rumah tangga. Berdasarkan data Badan Pusat Statistik NTT (2013) populasi ternak babi 1.583.052 ekor (2009), 1.724 .591 ekor (2010), 1.669 .705 ekor (2011), 1.697.252 (2012) dan 1.729.656 (2013). Bila dilihat dari data ini terjadi peningkatan mencapai 3,5\% per tahun, hal ini dapat menjadi indikator bahwa permintaan akan produk ini selalu meningkat. Dengan tingginya permintaan akan daging babi, menjadikan usaha ternak babi sebagai salah satu sumber pendapatan bagi masyarakat. Menurut Sution (2010), 
beberapa alasan ternak babi mempunyai arti penting dalam ekonomi di antaranya, karena babi dapat menghasilkan keuntungan yang relatif cepat dari modal yang dikeluarkan.

Kegiatan Ipteks bagi Masyarakat (IbM) ini memiliki kelompok yang berusaha dalam pembibitan ternak babi. Mitra umumnya sudah memiliki ternak babi namun masih dalam jumlah yang sangat kecil 1-2 ekor. Dalam usaha pembibitannya dalam setahun hanya satu kali beranak sehingga jarak perkawinan panjang hal ini tidak menguntungkan secara ekonomis. Produktifitas ini sangat rendah dibandingkan dengan babi yang memiliki produktifitas tinggi. Wahyuningsih et al. (2012) mengemukakan bahwa ternak babi dapat beranak dua kali dalam setahun dan sekali beranak dapat menghasilkan anak yang banyak dan babi juga mudah beradaptasi dengan lingkungan.

Sebelumnya mitra mengusahakan ternak babi untuk dijual sebagai ternak potong, namun hal ini juga mempunyai lama pemeliharaan yang panjang, kesulitan untuk mendapatkan babi bakalan yang mendorong mitra untuk mengubah usaha ke pembibitan ternak babi. Kelemahan - kelemahan tersebut disebabkan karena kurangnya pengetahuan mitra tentang kriteria bibit ternak yang baik, kurang terpenuhinya kebutuhan nutrien ternak yang menyebabkan pertumbuhan dan produksinya rendah, kurangnya pengetahuan tentang sistem perkandangan yang mendukung usaha peternakan babi tersebut.

Mitra terdiri dari 3 orang diketuai oleh Markus Nifu. Usaha di kelompok mitra ini disarankan usaha pembibitan, karena lahan yang dimiliki lebih sempit serta melihat peluang usaha penyediaan bakalan yang memiliki permintaan yang cukup bagus.

\section{METODE PELAKSANAAN}

Metode pendekatan yang digunakan untuk menyelesaikan permasalahan mitra yang telah disepakati bersama selama kurun waktu realisasi program IbM adalah :

a. Metode ceramah dengan menyampaikan informasi ipteks secara lisan kepada mitra yang pada umumnya mengikuti secara pasif. Informasi ipteks disampaikan oleh tim IbM. Adapun materi yang diberikan tentang penyusunan ransum ternak babi, perkawinan ternak babi, dan penanganan kelahiran.

b. Metode diskusi mitra beridiskusi dengan tim IbM dan nara sumber terkait permasalahan yang pernah dialami terkait materi yang telah diberikan. 
c. Metode praktek tim IbM memberikan kesempatan kepada mitra secara berkelompok untuk dilatih melakukan suatu proses.

d. Metode pendampingan, monitoring dan evaluasi pelaksanaan IbM

\section{HASIL DAN PEMBAHASAN}

Kegiatan IbM ini telah dilakukan untuk mengatasi beberapa permasalahan yang dihadapi mitra melalui kegiatan-kegiatan berikut :

\section{Koordinasi Kegiatan}

Koordinasi dengan mitra dilakukan oleh tim pelaksana untuk menyepakati tentang kegiatankegiatan yang akan dilakukan, jadwal pelaksanaan, serta bentuk peran mitra dan tim IbM.

\section{Perbaikan kandang}

Pembuatan kandang yang lebih memenuhi syarat kandang yang baik, pembuatan pakan yang sesuai dengan kebutuhan ternak, pembuatan kandang untuk ternak babi pembibitan di mitra Ukitauk, dalam kegiatan ini tim IbM menyediakan semua bahan-bahan untuk pembuatan kandang sedangkan proses pembangunannya dilakukan oleh anggota kelompok dan keluarga.
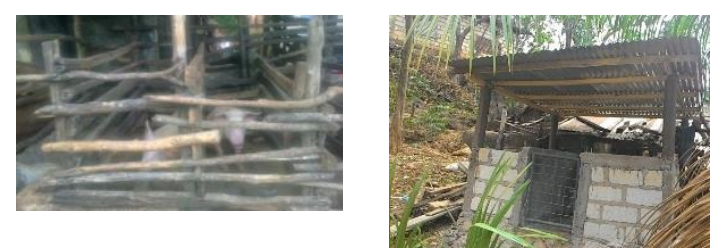

Gambar 1 . Kandang sebelum renovasi dan setelah renovasi

\section{Penyuluhan}

Kegiatan penyuluhan dilakukan oleh tim pelaksana IbM tentang hal-hal yang terkait dengan kegiatan pemeliharaan ternak babi khususnya pembibitan ternak babi. Materi penyuluhan ditampilkan pada Tabel 1.

Tabel 1. Materi Yang Disampaikan pada Kegiatan Penyuluhan IbM

\begin{tabular}{ll}
\hline Judul Materi & Pemateri \\
\hline $\begin{array}{l}\text { Pengolahan pupuk } \\
\begin{array}{l}\text { Penanganan kelahiran } \\
\text { ternak babi }\end{array}\end{array}$ & Tri A.Y Foenay \\
$\begin{array}{l}\text { Pakan Komplit ternak Koni } \\
\text { babi bunting }\end{array}$ & Theresia Koni \\
\hline
\end{tabular}


Pada kegiatan penyuluhan ini mitra mendengarkan penjelasan tim pelaksana IbM kemudian dilanjutkan dengan diskusi, dimana mitra bertanya tentang hal-hal yang kurang dipahami terutama yang berhubungan dengan materi yang dibawakan oleh masing-masing anggota pelaksana, dan dicarikan solusinya oleh tim pelaksana IbM.

\section{Demplot dan Pendampingan}

Kegiatan demonstrasi plot (demplot) dilakukan secara langsung oleh tim pelaksana yang dibantu oleh mahasiswa. Kegiatan tersebut lebih mudah dipahami oleh masyarakat karena langsung dipraktekkan bersama-sama dengan tim IbM. Demplot yang dilakukan adalah :

pembuatan pakan ternak, dalam kegiatan ini dibuat pakan sejumlah $300 \mathrm{~kg}$.

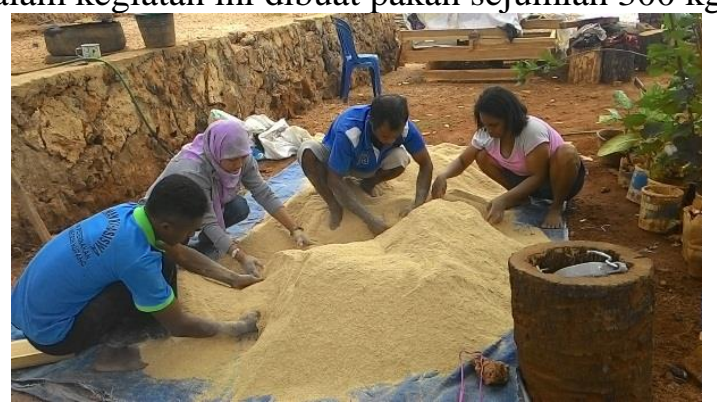

Gambar 3. Pembuatan Pakan Ternak

Pakan yang dibuat disesuaikan dengan kebutuhan ternak seperti yang ditampilkan pada Tabel 2.

Tabel 2. Rataan Kebutuhan Ransum Dan Air Ternak Babi

\begin{tabular}{llccc}
\hline \multirow{2}{*}{$\begin{array}{c}\text { Umur } \\
(\mathrm{mgg})\end{array}$} & $\begin{array}{l}\text { BB } \\
(\mathrm{kg})\end{array}$ & Rsm $(\mathrm{kg})$ & Air $(\mathrm{lt})$ & $\begin{array}{c}\text { Prot } \\
(\%)\end{array}$ \\
\hline $4-8$ & $5-10$ & $0.5-0.75$ & $0.75-0.5$ & 20 \\
$8-12$ & $10-20$ & $1.0-1.25$ & $2-3.5$ & 18 \\
$12-16$ & $20-35$ & $1.5-2$ & $3.5-4$ & $16-18$ \\
$16-20$ & $35-60$ & $2.2-2.7$ & $4-5$ & $16-18$ \\
20 & $60-100$ & $2.75-3.5$ & $5-7$ & 14 \\
Bunting & & $2-2.5$ & $7-9$ & 16 \\
laktasi & & $3-4.5$ & $15-20$ & 14 \\
Pejantan & & $2-2.5$ & $7-9$ & 14 \\
\hline Sumber: Sihombing (1997) & & &
\end{tabular}

Pakan yang diproduksi kemudian digunakan untuk kebutuhan ternak babi yang dipelihara oleh mitra. Formulasi dan kandungan nutrien pakan yang digunakan disajikan pada Tabel 3. 
Tabel 3. Pakan Babi Bunting Di Kelompok Maulafa

\begin{tabular}{|c|c|c|c|c|c|c|c|}
\hline $\begin{array}{l}\text { Bahan } \\
\text { Pakan }\end{array}$ & $\begin{array}{c}\text { Kompisisi } \\
(\%)\end{array}$ & $\begin{array}{c}\text { EM ( } \\
\text { Kcal/K } \\
\text { g) }\end{array}$ & $\begin{array}{l}\text { P K } \\
(\%)\end{array}$ & $\begin{array}{l}\text { LK } \\
(\%)\end{array}$ & $\begin{array}{l}\text { SK } \\
(\%)\end{array}$ & $\begin{array}{c}\mathrm{Ca} \\
(\%)\end{array}$ & $\begin{array}{c}\mathbf{P} \\
(\%)\end{array}$ \\
\hline Jagung & & 1526,3 & & & & & \\
\hline Kuning & 44,50 & 5 & 4,01 & 1,65 & 0,85 & 0,01 & 0,13 \\
\hline Dedak & 30,00 & 570,00 & 3,90 & 0,51 & 3,60 & 0,02 & 0,27 \\
\hline Konsentrat & 25,00 & 750,00 & 8,75 & 0,75 & 0,75 & 0,18 & 0,23 \\
\hline Mineral 10 & 0,50 & 0,00 & 0,00 & 0,0 & 0,00 & 0,03 & 0,02 \\
\hline Total & 100,0 & $\begin{array}{l}2846,3 \\
5 \\
\end{array}$ & 16,66 & 2,91 & 5,20 & 0,24 & 0,64 \\
\hline
\end{tabular}

\section{Pemeliharaan Ternak Babi}

Kegiatan ini dilakukan oleh mitra, yang rutin dilakukan adalah pemberian pakan, air minum serta pencucian kandang. Mitra juga dilatih untuk mendeteksi berahi yang merupakan hal yang penting dalam mendukung usaha pembibitan. Sihombing (1997) menyatakan bahwa ciri-ciri ternak babi yang berahi antara lain: vulva membengkak dan berwarna merah, keluar lendir putih bening, sering menaiki sesama ternak, dan bila punggungnya ditekan ternaknya diam saja.

Tim pelaksana mendampingi mitra dimana secara rutin sekali dalam seminggu mengunjungi mitra. Ketika ternak menunjukkan gejala berahi mitra menghubungi tim pelaksana, yang dilanjutkan dengan tindakan perkawinan secara alamiah dengan mendatangkan pejantan unggul dengan sistem pembayaran untuk pelayanan hingga ternaknya bunting.

Ketika ternak dinyatakan bunting dengan tidak menunjukan gejala berahi 14- 21 hari setelah perkawinan. Pada saat bunting pakan yang diberikan pun ditambah jumlahnya sebanyak $1 / 4$ dari pemberian sebelum kebuntingan. Kebutuntingan babi rata-rata selama 114 hari (Sihombing, 1997).

Kelompok peternak mitra akan menghubungi tim IbM bila babi menunjukkan gejala akan beranak. Tanda- tanda seekor ternak betina bunting akan beranak seperti perut turun, vulva mengendor, vulva membengkak berwarna merah dan keluar lendir, ambing mengeras, nafsu makan berkurang, ternak betina ingin membuat sarang atau alas tidur, gelisah, serta kurang lebih $1 / 2$ jam sebelum anak pertama lahir induk rebah menyamping, (Ardana, 2008) . 


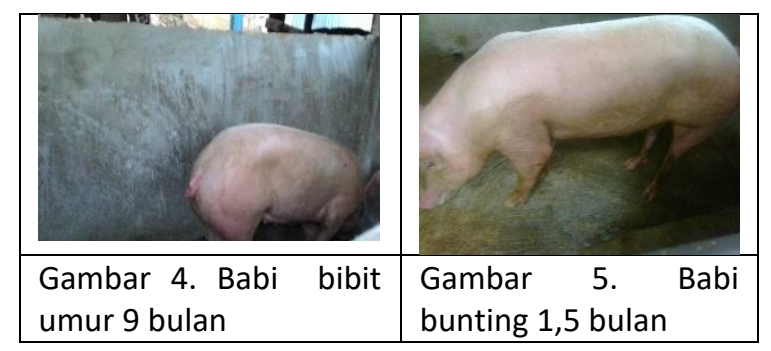

Setelah babi menunjukkan gejala beranak maka mitra menghubungi tim IbM untuk bersama-sama menangani atau membantu kelahiran ternak babi tersebut, babi IbM beranak sejumlah 8 ekor, kemudian dilakukan pemberian vitamin dan obat-obatan pada induk dan anaknya, serta pemotongan gigi, ekor pada anak babi. Ini dilakukan oleh mitra berdasarkan petunjuk yang diberikan oleh tim IbM. Ternak babi yang dilahirkan dipelihara bersama induknya selama 1,5 bulan kemudian dilakukan penyapihan dan pemasaran anak babi tersebut.

Kegiatan ini dinyatakan berhasil dengan adanya pendapatan yang diperoleh dari usaha pemeliharaan ternak babi pada mitra IbM. Maulafa memperoleh anak babi sapihan, bila dilihat dengan selisih biaya pakan yang dikeluarkan maka terjadi penghematan biaya pakan sebesar Rp. 256,500 pada mitra, bila dibandingkan dengan menggunakan pakan komersial

\section{Monitoring dan Evaluasi}

Dalam rangka mensukseskan kegiatan IbM, maka tim pelaksana selalu melakukan monitoring dan evaluasi (Monev) terhadap setiap tahapan kegiatan. Monev dilakukan untuk memantau perkembangan usaha peternak babi mitra. Permasalahan yang ditemui dalam kegiatan monitoring segera diselesaikan secara bersama-sama.

\section{Faktor Pendukung dan Penghambat}

Faktor pendukung terlaksananya kegiatan IbM di lapangan adalah :

1. Partisipasi mitra

Mitra berpartisipasi aktif dalam setiap tahapan kegiatan IbM.

\section{Pasar}

Pasar babi bakalan sangat luas karena konsumen mendatangi mitra dan masih kurang memenuhi permintaan pasar.

Faktor-faktor yang menjadi kendala yang dihadapi selama pelaksanaan kegiatan IbM adalah mitra tidak memiliki modal yang cukup sehingga dapat memperbanyak jumlah ternak bibit yang disediakan. 


\section{KESIMPULAN}

Berdasarkan hasil kegiatan yang telah dilaksanakan maka dapat disimpulkan bahwa kegiatan IbM pembibitan ternak babi Maulafa ini telah terlaksana dengan baik dan berhasil, hal ini dikarenakan partisipasi aktif mitra selama kegiatan IbM dan bermanfaat bagi mitra yaitu peningkatan pendapatan mitra.

\section{DAFTAR PUSTAKA}

Ardana. E. B. 208, Ternak Babi Manajemen Reproduksi Produksi dan Penyakit. Udayana Univercity Press, Denpasar.

Sihombing. D. T. H. 1997, Ilmu Ternak Babi. Gajah Mada Univercity Press. Yogyakarta.

Statistik Peternakan dan Kesehatan hewan. 2013. Direktorat Jenderal Peternakan dan Kesehatan Hewan. Kementerian Pertanian.

Sution. 2010. Beternak Babi. Balai Pengkajian Teknologi Pertanian. Kalimantan Barat.

Wahyuningsih N., Y.B.P. Subagyo, Sunarto, S. Prastowo dan N. Widyas. 2012. Performan Anak Babi Silangan Berdasarkan Paritas Induknya. J. Sains Peternakan 2: 56-63. 